\title{
Aesthetics and Ethics Intertwined: Fictional and Non-Fictional Worlds
}

\author{
JONATHAN LOCKE HART
}

\begin{abstract}
Montaigne and Las Casas are important thinkers and writers, as are many others, including Shakespeare, as a poet, whose work is complex enough in its modernity that it would be hard to condemn him as a poet as Plato did Homer. Aristotle analyzed Greek tragedy to see how it worked in terms of a framework of anagnorisis and catharsis, that is, recognition and the purging of pity and terror. Shakespeare revisits and reshapes Homer in Troilus and Cressida and remakes Plutarch in Julius Caesar and Antony and Cleopatra while playing on the classical epic and mythological themes in Venus and Adonis and Rape of Lucrece. Plato, a poet as well as a philosopher, and a great writer if one does not like those categories, may have feared the poet within himself. Although assuming with Plato that philosophy is more universal and just than poetry, Aristotle takes the analysis of poetry and drama seriously in Poetics, and also discusses ethics, aesthetics and style in Rhetoric. So, while I discuss Plato as a framework, I am not presuming that writing on the relations among the good, the true, the just and the beautiful stop with him. I am also making the assumption that Las Casas, Montaigne, Shakespeare and other poets and writers deserve to be taken seriously in the company of Plato. Las Casas and Montaigne respond to radically changing realities and shake the very basis of traditional ethics (especially in understanding of the "other") and work in harmony with the greatest poets and writers of a new era often called modernity like Shakespeare, who is in the good company of Manrique, Villon, Ronsard, Du Bellay, Juan de la Cruz, Luis de León, Lope de Vega, Quevedo and Calderón. Long before, Dante and Petrarch were exploring in their poetry ethical and aesthetic imperatives and broke new ground doing so. Nor can Las Casas and Montaigne be separated from other great writers like Rabelais and Cervantes, who carry deep philosophical and ethical sensibility in their work while responding to reality by providing aesthetically - even sensuously - shaped images that always leave a margin for ambiguity because conflicts are part of an ambiguous reality.
\end{abstract}

Keywords: aesthetics; ethics; poetry; writing; philosophy; mimesis

Since the art for art's sake movement and since Romanticism, the aesthetic has sometimes been separated from ethics. Traditionally, Socrates, Plato and Aristotle saw the good, the true, the just and the beautiful as being intertwined. 
In fact, the charges that Socrates and Plato brought against Homer and the poets was that they seduced others with their poetic art from what is good or ethical. The poets themselves represent scenes and characters that refract or challenge with their art the moral realm of their societies, so that Plato's interesting critique seems partially true or partially false depending on the point of view. This article will discuss the texts of philosophers, poets and others - mainly Plato, Shakespeare, Las Casas and Montaigne - in order to argue that aesthetics and ethics are inextricable, but that they also have many realities or facets, and that the connection is not monolithic. There are, then, different cultural and historical contexts that should qualify any sense that there is one point of view that establishes the relation between the aesthetic and the ethical. Plato will provide a good place to begin, but is not an end in and of himself.

Plato's work represents poets and philosophers, and raises questions of the moral value of poetry and its effect on individual and polity (see Destrée and Herrmann 2011, especially the chapters by Collobert, Lear, Marušič, Singpurwalla). The Platonic Socrates questions Homer as an authority, and indeed takes Homer as an instance to assert the danger of poetry for the soul and the city. This is a new ethical vantage. Historically, various views explore the relation between the good and the beautiful, as well as calling into question the relation between words and reality. After discussing Plato mainly in terms of Aristophanes, this article will look briefly at different views of the colonization and settlement of the New World and the connection between Natives and invaders (settlers) and at an aesthetic and ethical dimension of narrative in Shakespeare's Rape of Lucrece and Hamlet. The texts under discussion here, of Las Casas, Montaigne and Shakespeare, will suggest that the ethics of representation, the shades of words, shift and query themselves, but the article can suggest one contour of this topic and not a full topography. ${ }^{1}$ From Plato onward, the critical spirit and the creative spirit are closely related and sometimes vie. It is possible that the very close connection between aesthetics and ethics, something inextricable, manifests itself in the very querying, questing and exploration.

The Works Cited contains extra texts employed in a longer version of this article and kept as, I hope, a valuable resource for the reader. Please see Armstrong 1998; Auerbach 1953; Beistegui 2012; Belfiore 1984; Belhaj 2010; Burnyeat 2012; Doran 2017; Halliwell 1988; Hart 1991a, 1991b, 2003, 2006; Hyland 2008; Kosman 2010; Miller 2011; Moss 2012; Mualem 2012; Naddaff 2002; Hehamas 1982; Notomi 2011; Palumbo 2013; Pettersson 2016; Zakai 2017. 


\section{A Particular Background of Mimesis: Aristophanes, Plato and Sidney}

A comic dramatic poet such as Aristophanes has ideas about mimesis, so it is not for philosophers, like Plato, alone to discuss. Imitation or representation is far from being simply reflective: it has many dimensions, as Aristophanes, Plato and others explored. According to Pappas, this poet influenced Plato in considering imitation or representation. The moral dimension of poetry is embedded in discussions of mimesis among the ancient Greeks. The very intricacy of mimesis is something that has filled many a commentary for thousands of years, so that I discuss a few aspects only bring into focus briefly the relations among truth, justice and beauty (see Pappas 2016). Mimesis is a key part of what today we might call ancient aesthetics (see, for instance, Woodruff 2015, as well as other fine contributions; see also De Caro 2013).

Poetry and philosophy are in conflict in this debate over mimesis. According to Pappas, authors before Plato used mimesis as describing a poetic process, although the comedies of Aristophanes, which discuss Euripides and tragedy (Birds 787, 1444; Clouds 1091; Plutus 423-24, cited in Pappas 2016), comment on mimeisthai and mimesis in consistently pejorative ways (see Pappas). Before Plato, Aristophanes has a moral critique of poetry, even if Aristophanes lampoons Socrates in Clouds (see Pappas and Nussbaum 1980). Aristophanes has Socrates say to Strepsiades: "No scoffing; do not copy those damned comic poets" (Aristophanes). The playwright sets up a satire on Socrates in which the philosopher dismisses comic poets and, by implication, Aristophanes.

Pappas argues that Aristophanes' influence on Plato extends to the nature of mimesis, employing it in a technical sense that describes what actors do in a play and in a way that also suggests fraud or concealment. Whereas Frogs includes the rivalry between Aeschylus and Euripides, Women Celebrating the Thesmophoria deems mimesis a disruption of life opposed to nature (Pappas 2016). Thus, Aristophanes, a dramatic poet, is one key to the debate on mimesis, which itself is at the heart of the connection between the ethical and the aesthetic.

In the Tenth Book of the Republic, Plato speaks of beauty in art and poetry, but more importantly Plato asks what leads a mind to knowledge and the Ideas or Forms. Poems fail to be beautiful the way philosophy is. Poetry obstructs the ethics of beauty and recognition through the beauty of knowledge. For Socrates, imitation involves the illusion of truth through the seduction of literary beauty. Homer's representations are three removes from reality and do not really show knowledge and truth. Plato sets out, through Socrates, to question the reputation of Homer and the poets for being wise and worthy of study for ethical and philosophical truth. The agon or contest, then, is between philosophers and 
poets for the guidance or education of others in the ways of justice and truth. But later poets and writers also follow in the footsteps of Aristophanes, so while Plato's critique is suggestive, it should not be internalized as proof that poetry is simply dangerous and unethical. On the contrary, poets like Shakespeare, and other early modern or Renaissance poets are far too complex in the ways they intertwine aesthetics and ethics: it is hard or perhaps inadvisable to separate the two. For the sake of this argument, I would say, with Philip Sidney, answering Plato and some of those like Stephen Gosson (an actor and writer who seems to have dedicated work to Sidney without Sidney wanting that honour) who were antimimetic or antitheatrical (perhaps because of the religious climate in the city of London and the rise of Protestantism and Puritanism in England and northern Europe), that poetry is more universal than philosophy because its concrete images are less abstract and can be apprehended and remembered and move the reader to virtue (Sidney). However, I am not interested in ranking the ways or knowing fields or disciplines, because I think we need them all to understand illusion and reality.

Socrates, Plato and Aristotle examined representation after others among the Greeks and were also before the moderns in their uses of imitation, for instance in the New World. In what follows, I wish to discuss the ways Las Casas, Montaigne and others raise moral issues in the texture of their prose and poetry and in the context of representations of European encounters with the New World. Las Casas may be more theological than the philosophical Montaigne, but both share a moral domain in their form and content, style and substance.

\section{New Worlds, New Writers: Las Casas and Montaigne}

Imitation is an important matter in the exploration and settlement of the Americas. In Representing the New World (Hart 2001), I tried to demonstrate the rhetorical intricacy of the texts of travel and their significance so as to explore the ambivalent and contradictory responses of France and England to Spain from the first decade after Columbus' landfall in the western Atlantic to the beginning years of the eighteenth century, and to show the importance of translations in both disseminating and shaping knowledge concerning the colonizing of the western hemisphere. The textual and rhetorical nature of the representation of Spain in English and French texts about the Americas was my major focus, and relates to the whole debate on imitation we have been discussing in Plato. A typology also existed between the Old World and the New World itself. French and English representations of the Spanish were connected with the Dutch revolt against Spain in the Netherlands. Europeans tended to represent the Americas 
HART

when reflecting or refracting them in Europe. Early modern Spain, England and France employed the trope, which occurred in the classical world, of translatio imperii, or the translation of empire (see Breisach 1983: 13, 172-179). This trope was related to the ambivalence in the English and French representations of the link between Spain and the Natives and their own countries and the indigenous peoples. Often this translation entailed an overcoming of other "barbarous" cultures and influences of a previous empire (see Said 1978, Pagden 1986: 14-26). The translation of translation and the representation of representation became part of the expansion of Europe. As Plato saw, text and action were inextricably linked. Here, the ethical and aesthetic dimensions of texts extend as much to the prose texts of Plato, Las Casas and Montaigne as the poetic texts of Shakespeare.

The translation from Spain to France and England may be observed in Montaigne's relation to the Spanish and in Florio's translation of Montaigne into English. When Bartolomé de Las Casas, André Thevet, Jean de Léry, Michel de Montaigne and others employ other cultures to criticize European culture, they follow classical works like Tacitus' Germania. In Tacitus, the masculine German barbarians are a reproach to the effeminate Romans (see Burke 1981). For Florio, in a good way, translation moved knowledge from the universities into the commons (see Boutcher 1991). Translation is a kind of representation and, like representation itself, is a way of knowing. Mimesis, imitation and representation are equivalents to what I term "representation." The Renaissance notion of imitation was at the centre of its translation theory: imitation of the classics entailed borrowing the best from them (see Cave 1979, Worth 1988: 1-11). Translation also involved a challenge to the Spanish, French and English texts about the New World as well as an imitation of them (see Michel 1960: 68). In a kind of intertextuality, the English and French drew on texts by Spaniards and those of each other, and works by or influenced by classical views found in Aristotle, Pliny, Cicero and others (see Pagden 1986: 10). The English and French had to imitate and be critical of the imitation or representation of the New World by the Spaniards (see Pagden 1986: 10).

The Black Legend of Spain was part of this imitation or representation, this mimetic use of texts in a call to action, expansion or colonization (see DeGuzmán 2005, Greer et al. 2007). One of the major ways to disseminate this anti-Spanish sentiment among other nations was the use, against Spain, of the work of Las Casas (see Clayton 2012, Hernández 2015). This strategy was to employ Spain against Spain. Las Casas, a critic of Spanish colonization but a supporter of the Spanish emperor and empire, who was first a landowner in the New World and then a religious, may well have been surprised had he lived to see the use of texts in the case of the rivals of Spain (Elliott 1992 [1970]: 92). 
The French and English employed Spain's self-criticism through vernacular translations, particularly that of Las Casas, who was used as a weapon against Spain in France beginning in 1579 and in England in 1583, and on and off for centuries. His account of the destruction of the Indies, for example, was printed four times during the Spanish-American War of 1898 (see Ingalls 1898, Saint-Lu 1982, Hart 1999). Las Casas' Brevissima relación (1552) was sympathetic to the indigenous peoples of the New World and had a moral interest to their plight because of his Christian duty and his empathy for the Natives as humans. His rhetorical style, full of extremes and repetition, was meant to highlight his moral indignation. This stylistic excess or this hyperbolic strategy was something taken up not simply by Las Casas, but by the translators and printers. The titles, for instance, are an indicator of the extremes of moral indignation, sometimes verging on propaganda. This book was translated, often the first of the nine constituent tracts or the first and some selections from the remaining tracts, into French with various titles: Tyrannies et cruautez des Espagnols (Paris, 1579; Paris, 1582; Rouen, 1630), Histoire admirable des horribles insolences (Geneva, 1582), Le miroir de la tyrannie espagnole (Amsterdam, 1620), and, in the same year and with the identical publisher, Le miroir de la cruelle \& horrible tyrannie espagnole (see Saint-Lu 1982: 159-170). The French titles were sensational. The rather bland English translation of the French version, The Spanish Colonie (1583) became, in 1656, the more melodramatic and plaintive The Tears of the Indians.

As we have seen, Bartolomé de Las Casas's A Short Account of the Destruction of the Indies (1542, pub. 1552) was a key text in the European expansion to the New World, and that translation was part of this textual representation. Las Casas was part of a wider religious and ethical debate, which also had textual dimension in rhetoric, law and theology. The Spanish crown allowed the debate of 1551 between Las Casas and Juan Ginés de Sepúlveda over the treatment of the Native peoples (Pagden 1986: 109-118). Whereas Las Casas saw Christian universal history in the conversion of the Indians, who were human, Sepúlveda supported the Spanish monarchy and empire and denied the significance of the conversion of the Indians, whom he thought were not entirely human. Like Oviedo, Sepúlveda argued against the humanity of the Natives, whereas Las Casas defended them. So, these texts and debates have textual power or rhetorical persuasion, in trying to influence king and court and a wider reading public. The texts had a performative power, a kind of aesthetic or rhetorical aspect that urged what the author thought was the ethical path for religion and state. Las Casas expressed outrage at the genocide By defending the humanity of the Natives, Las Casas defied Sepúlveda's application of Aristotle's theory of natural slavery (see Quinn 1971). Whereas the one looked to the New Testament, the other went back to the ancient Greeks. 
HART

Michel de Montaigne also had a classical education, so it is not surprising that he too would be part of a discussion of imitation, something so important in Plato. In "Des Cannibales” (1580), Montaigne used a classical context, including the Greek habit of calling all foreign countries barbarous and Plato's representation of Solon's account of Atlantis, to criticize French and European expansion and commerce in the New World (Montaigne 1906 [1588] I: 167). This essay is typological, is about France and the New World (Quint 1995: 168).

In writing about cannibals, Montaigne had stressed the French and Europeans in the New World. In "Des Coches" ("Of Coaches"), he speaks about the Spanish and wonders why the new lands could not have been conquered under the Greeks and Romans. In that way, for Montaigne, the ancients would bring the peoples virtue rather than teaching them European avarice and "all sorts of inhumanity and cruelty and pattern of our customs." (Montaigne 1906: III. 399-400, my translation here and below). Instead, in search of pearls and pepper, the Europeans had exterminated nations and millions of people, which Montaigne called "mechanical victories" (Montaigne 1906: II.314). The king of Mexico, in Montaigne's account, was subjected to Spanish cruelty and torture, which diminished Spain and not the victim (Montaigne 1906: II.401). These and other atrocities were a source of Spanish pride: "We have from themselves these narratives, for they not only confess but publish and extol them" (Montaigne 1906: III.401). The Spaniards, according to Montaigne, exceeded the force necessary in conquest and had met with providential justice (Montaigne 1906: III.401, see Montaigne 1921). Taken in context, then, Montaigne's comments on the Spaniards and their treatment of the Natives were not as brilliant, elegant and provocative as his work is, original or seminal. In the texts about colonization of the New World, there is a kind of imitation, not simply of the ancient authors but among the French and the English in regard to the Spanish.

Part of textual imitation is intertextuality, which can involve one text imitating another in the original language or in translation. The ethics of the text are bound up with the style, and in Montaigne's case, that is elegant. The ethics or writing and reading endure most when the text has a beauty to attract or even seduce the reader into reading again. Poets and writers generally, like Las Casas and Montaigne, create texts in which the aesthetic and ethical are intertwined, but even if these writers - and the poets, Homer and Shakespeare, might well be surprised that the authorities and the voices of philosophy and theology could miss the moral dimension of their work. Aesthetics has more dimensions than seduction and misleading youth. That intertwining in these writers and poets is the beautiful truth of form and content, as Plato knew and suspected. 
Aesthetics and Ethics Intertwined: Fictional and Non-Fictional Worlds

\section{Shakespeare}

Shakespeare, who read Ovid and Montaigne, also married ethics and aesthetics. Ovid crosses temporal and spatial boundaries, as do myths such as visual and textual representations of Lucretia, so Shakespeare's connection to Ovid or this story from mythology is part of a wide network of influence, allusion, transformation, showing that stories and literature travel on trade, political and social routes (see Donaldson 1982, Enterline 2000). In Rape of Lucrece, Shakespeare gives language to the narrator and characters to appeal to the reader, thereby moving him or her to virtue or pleasure or both. This use of language in Rape of Lucrece I have explored in detail in earlier work, so I will mention the broad outlines here as part of this argument (see Hart 1994, Hart 2009; for recent work that focuses on Lucrece or includes discussions of it, see Lees-Jeffries 2013, Starks-Estes 2014, Jacobson 2014). Shakespeare represents the friction between persuasion and seduction, between consideration and ethical distance, between form and content. This tension opens a space for the aesthetics and ethics of reading. In all this, meaning is made and unmade in the poetic and rhetorical contract between writer and reader through narration and characterization through the poetry itself.

The Rape of Lucrece represents the telling of tales during the siege of Ardea. That telling leads to further reports and stories, especially Tarquin's narrative of seduction and Lucrece's tale of rape. Shakespeare uses a narrative ethic: he uses narrative to explore love, lust, and violence. Rhetoric, persuasion, and communication all bear on this connection between narrative and ethics. Here, I draw attention to this connection, and elsewhere I have performed a detailed analysis of how the speaker relates to the audience and the writer to the reader (for other more recent views of Lucrece, see Ritscher 2009, Sanchez 2013, Meek 2014; also see Hart 1992a, Hart 2009). Shakespeare's poem invites an examination of these closely related and overlapping categories-characters as narrators, the principal narrator, and the ways the reader is implicated in the narration (on narrative theory, see Culler 1981: 169-186.)

Writing, reading, aesthetics and ethics all relate. Central to my concern in this article is to stress that in Rape of Lucrece the act of interpretation connects the characters, principal narrator, and reader, and does not allow any of' them to be innocent bystanders to the story. The three categories of characters as narrators, principal narrator, and the participation of the reader in narrative overlap so much that it is a temptation to discuss them simultaneously to reenact their complex effects, but in practice they can also be analyzed separately (on the relation between action and character, see Aristotle 1971: 51). For instance, the narrator helps shape our response as readers by framing and interpreting the tales 
HART

Tarquin tells to himself and to Lucrece in order to enact the rape, the narratives Tarquin and Lucrece tell each other, the story Lucrece must tell of the rape, and the responses that Lucretius, Collatine, and Brutus have to Lucrece's account of Tarquin. Here, the stories come full circle. Here and in my brief discussion of Hamlet, we can observe that narrative may be as much an interpretation of events or a response to another tale as a tale itself. In Shakespeare's poem, the tales are contextual, a part of a series: he uses the narrator as a telling transition between the narratives of characters and as a means of distinguishing between story and plot, the events and their representation, this making an aesthetic and ethical connection between form and content, the way the story is arranged and told and the story itself. Like the writer, the reader makes his or her way through the narrative as a heuristic means of interpreting the events of the story. Is the reader complicit in the rape with its private and public connotations? Is the reader seduced through the erotic poetry and the persuasive rhetoric, looking at Lucrece through the eyes of Tarquin. Although the acts of writing and reading are more intricate than a simple identification, the narrative does take the reader into the world of rape, an uncomfortable position, one that transgresses law and that is violent. The act of discovery and interpretation is part of the aesthetic and ethical experience of the tale of the rape of Lucrece, which itself was represented in image and text in a kind of inter-representational nexus.

Elsewhere I have also examined narrative in Hamlet, so I will be brief here (see Hart 1991, Hart 2009). The stories of Ovid and of Lucretia, as we observed, travel across boundaries over time, and Shakespeare's sources for Hamlet are generally thought to be a Latin text by Saxo Germanicus and a French one by Belleforest, something Israel Gollancz discussed in the 1920s (see Gollancz 1926, Bullough 1957, Muir 1977). The forms and contents of stories are inextricably bound, and this is true on the stage as well as in non-dramatic poetry and prose genres like the novel. Story-telling occurs in the theatre and in lyric and narrative poetry. The delayed and splintered story of the Ghost in Hamlet is also an instance of exposition in a complex situation: Barnardo and Marcellus retell the tale about the Ghost's appearance to Horatio, who is a sceptical narratee (I.i.). Moreover, the Ghost interrupts Barnardo's tale about the Ghost and serves as a dumb show that tests Horatio's scepticism. The speech of the narration and of the characters' address to the Ghost contrasts with his silence and his motions. The Ghost's horrible narrative affects the rest of the play and, subsequently, is never far out of Hamlet's mind or that of the audience. Hamlet and the Ghost make Horatio and Marcellus swear not to tell the story of what they have seen. The Ghost's narrative leads Hamlet to announce his putting on of "an antic disposition" (I.v. 172). The murder the Ghost tells about, how his brother Claudius killed him, affects this drama of revenge and of medication of 
life and death. The splintered narrative in the play is a way that Hamlet and the theatre audience and reader absorb his ethical dilemma in a Christian context. The "To be or not to be" soliloquy reinforces this dilemma of life and death in this milieu of revenge and Christian doctrine. How does one have a Christian revenge tragedy different from the closet revenge plays of Seneca?

Metatheatre or metadrama is a way in which self-conscious theatricality occurs in the theatre. Shakespeare uses this technique in various speeches, such as York's "As in a theatre" speech in V.ii. of Richard II (1595) or the Pyramus and Thisbe play that the rude mechanicals put on for Duke Theseus and the court in A Midsummer Night's Dream (1595) and the tavern "play" between Hal and Falstaff in the tavern scene at II.iv. of 1 Henry IV (1597). They often combine the tale-telling of stories and the representation of the theatre. Another instance, in which showing and telling are mixed, in an intertwined representation of the aesthetic and the ethical, is the play-within-a-play, the Mousetrap (see Aldus 1977, Bloom 2003). This internal play includes Hamlet's narrative commentary. It also combines narration and dumb show in a manner that parallels and amplifies the two meetings with the Ghost (and the additional reported sighting) (III.ii.). Furthermore, Shakespeare brings together the dumb show, Hamlet's commentary, and a highly stylized play with narrative speeches, with the reactions of Claudius, Gertrude and other characters as a means of showing the close relation, and tension, between showing and telling, the teller, tale and audience. As in Rape of Lucrece, the intricacy of the form and content of the narrative creates a complex aesthetic and ethics. As Pappas says about Greek drama representing multiple perspectives, I am not the first to note that in Shakespeare's plays or even his non-dramatic poetry. John Keats, for instance, spoke of Shakespeare's negative capability, his empathy with all characters in which he does not take a singular aesthetic or ethical stance (for writers, on Shakespeare, see Leinwand 2016). The German Romantics, like the Schlegel brothers, Tieck and Solger, also noted this aspect of Shakespeare's art. This multiplicity, something I studied and wrote about in the 1970s and 1980s, is also evident in Shakespeare's history plays (Hart 1983, Hart, 1992b; for recent works on the history plays, see Karremann 2016, Lake 2016).

\section{Conclusion}

The mimetic or imitative or representational is unstable and calls into question the relation between word and world, beauty and truth, so that the intertwined realms of the aesthetic and ethical are connected but also uncertain. Each historical context from Plato onward suggests that circumstances, assumptions 
HART

and tastes alter over time. Among Plato's texts there are differences in the discussion of imitation, which affects the sense of reality, the relation between language and the world. Those writing later, consciously or not, are part of this representational or mimetic network. That means, to echo T. S. Eliot, they also modify the tradition with their own individual talent. In representing the New World, Las Casas and Montaigne imitate classical models like Herodotus and Plato as well as a new land that is changing Europeans views of the world and of representation itself. In this context, as we have seen, Plato may well have been influenced by Aristophanes, a comic poet of the theatre.

There are ethical questions for Las Casas and Montaigne as much as there are for Plato. The way they use language, their rhetoric and style, affects how the reader receives the truth claims and content - the ethics - of the texts. The same is true for Shakespeare's use of narrative in The Rape of Lucece and in Hamlet. The reader or theatre audience contend with showing and telling and so with the very intricacy of representational technique. The way of discovery or the heuristics of the text is an ethical as well as aesthetic act. Something I am asserting in this article is that the Greek intertwining of the aesthetic and ethical, of beauty and truth, as John Keats saw, is inextricable. Poets and writers, and not just philosophers, understand this interweaving in theory and practice. If a work is simply didactic without beauty, it fails to endure. If it is art for art's sake in the very tension between beauty and truth, beauty being itself, then it is more difficult to recognize the truth or ethics of the text. In fact, the drama of meaning is through a multiplicity of views over time and the tension between beauty and truth. Aesthetic ethics and ethical aesthetics are the oxymorons that are there in philosophy and poetry, even when they are rivals. That is the hidden and sometimes not so hidden ground.

\author{
Jonathan Locke Hart \\ jonathanlockehart@hotmail.com \\ Shanghai Jiao Tong University, School of Foreign Languages \\ No. 800 Dongchuan Road, Minhang District \\ Shanghai 200240 \\ CHINA
}

\title{
Works Cited
}

Aldus, P. J. 1977. Mousetrap: Structure and Meaning in Hamlet. Toronto: University of Toronto Press.

Aristophanes. The Clouds. - http://classics.mit.edu/Aristophanes/clouds.html (13.11.2017). 
Aesthetics and Ethics Intertwined: Fictional and Non-Fictional Worlds

Aristotle. 1971. Poetics VI:5. - H. Adams, ed., Critical Theory Since Plato. New York: Harcourt Brace Jovanovich.

Armstrong, J. 1998. History lesson. - D. D. Moses, T. Goldie, eds., An Anthology of Native Canadian Literature in English. Second Edition. Toronto: Oxford University Press.

Auerbach, E. 1953 [1946]. Mimesis: The Representation of Reality in Western Literature. W. R. Trask, trans. Princeton: Princeton University Press.

Beistegui, M. de. 2012. Aesthetics After Metaphysics: From Mimesis to Metaphor. New York: Routledge.

Belfiore, E. 1984. A theory of imitation in Plato's Republic. - Transactions of the American Philological Association, 114, 121-146.

Belhaj Kacem, M. 2010. Inesthétique \& mimèsis: Badiou, Lacoue-Labarthe et la question de l'art. Paris: Lignes.

Bloom, H. 2003. Hamlet: Poem Unlimited. New York: Riverhead Books.

Boutcher, W. 1991. Florio's Montaigne: Translation and Pragmatic Humanism in the Sixteenth Century [Unpublished doctoral dissertation]. University of Cambridge.

Breisach, E. 1983. Historiography: Ancient, Medieval \& Modern. Chicago: University of Chicago Press.

Bullough, G. 1957. Narrative and Dramatic Sources of Shakespeare. London: Routledge and Kegan Paul.

Burke, P. 1981. Montaigne. Oxford: Oxford University Press.

Burnyeat, M. F. 2012. Art and mimesis in Plato's Republic. - A. Denham, ed., Plato on Art andBbeauty. Houndsmills: Palgrave, 54-71.

Clayton, L. A. 2012. Bartolomé de las Casas: A Biography. New York: Cambridge University Press.

Collobert, C. 2011. Poetry as Flawed Reproduction: Possession and Mimesis. - P. Destrée, F.-G. Herrmann, eds., Plato and the Poets. Leiden and Boston: Brill, 41-62.

Cave, T. 1979. The Cornucopian Text. Oxford: Clarendon Press.

Culler, J. 1981. The Pursuit of Signs: Semiotics, Literature, Deconstruction. Ithaca: Cornell University Press.

De Caro, E. 2013. Forme della Mimesis: Momenti del sapere estetico nella cultura classica. Milano: Mimesis.

DeGuzmán, M. 2005. Spain's Long Shadow: The Black Legend, Off-whiteness, and AngloAmerican Empire. Minneapolis: University of Minnesota Press.

Destrée, P., F.-G., Herrmann, eds. 2011. Plato and the Poets. Leiden: Brill.

Donaldson, I. 1982. The Rapes of Lucretia: A Myth and Its Transformations. Oxford: Clarendon Press.

Doran, R. 2017. The Ethics of Theory: Philosophy, History, and Literature. Bloomsbury Academic.

Elliott, J. 1992 [1970]. The Old World and the New 1492-1650. Cambridge: Cambridge University Press.

Enterline, L. 2000. The Rhetoric of the Body from Ovid to Shakespeare. Cambridge: Cambridge University Press. 
HART

Gollancz, I., ed. 1926. The Sources of Hamlet with Essays on the Legend. Oxford: H. Mifford, Oxford University Press.

Greer, M. R., W. D. Mignolo, M. Quilligan, eds. 2007. Rereading the Black Legend: The Discourses of Religious and Racial Difference in the Renaissance Empires. Chicago: University of Chicago Press.

Halliwell, S. 1988. Plato Republic Book 10: With Introduction, Translation, and Commentary. Oxford: Aris \& Phillips.

Hart, J. 1983. Irony in Shakespeare's Second Tetralogy [Unpublished doctoral dissertation]. Toronto: University of Toronto.

Hart, J. 1991a. Narrative, narrative theory, and drama: The Renaissance. - Canadian Review of Comparative Literature / Revue Canadienne de Littérature Comparée 18 (2/3), 117-165.

Hart, J. 1991b. The crisis in narrative: Language, tale and drama in the Renaissance. Canadian Review of Comparative Literature / Revue Canadienne de Littérature Comparée 18 (2/3), 365-392.

Hart, J. 1992a. Narratorial strategies in The Rape of Lucrece. - Studies in English Literature, 1500-1900, 32 (1), The English Renaissance, 59-77.

Hart, J. 1992b. Theater and World: The Problematics of Shakespeare's History. Boston: Northeastern University Press.

Hart, J. 1999. The black legend: English and French representations of Spanish cruelty in the New World. - Comparative Literature Today: Theories and Practice / La Littérature comparée d'aujourd'hui. Théories et réalisations. Paris: Champion, 375-387.

Hart, J. 2001. Representing the New World: The English and French Uses of the Example of Spain, 1492-1713. New York: Palgrave.

Hart, J. 2003. Seeing double: Crossing boundaries here and there in some Canadian women poets. - A world of local voices. Germany: Königshausen \& Neumann, 29-42.

Hart, J. 2006. Interpreting culture: Literature, Religion, and the Human Sciences. New York and London: Palgrave Macmillan.

Hart, J. 2009. Shakespeare: Poetry, History and Culture. New York: Palgrave Macmillan. Hernández, B. 2015. Bartolomé de Las Casas. Barcelona: Taurus.

Hyland, D. A. 2008. Plato and the Question of Beauty. Bloomington: University of Indiana Press.

Ingalls, J. J., ed. 1898. America's War for Humanity Related in Story and Picture, Embracing a Complete History of Cuba's Struggle for Liberty, and the Glorious Heroism of America's Soldiers and Sailors. New York: ND Thompson Company.

Jacobson, M. E. 2014. Barbarous Antiquity: Reorienting the Past in the Poetry of Early Modern England. Philadelphia: University of Pennsylvania Press.

Karremann, I. 2016. The Drama of Memory in Shakespeare's History Plays. Cambridge: Cambridge University Press.

Kosman, A. 2010. Beauty and the good: Situating the Kalon. Classical Philology, 105, 341-357.

Lake, P. 2016. How Shakespeare Put Politics on the Stage: Power and Succession in the History Plays. New Haven: Yale University Press. 
Aesthetics and Ethics Intertwined: Fictional and Non-Fictional Worlds

Lear, G. R. 2011. Mimesis and psychological change in Republic III. - P. Destrée, F.-G. Herrmann, eds., Plato and the Poets. Leiden and Boston: Brill, 195-216.

Lees-Jeffries, H. 2013. Shakespeare and Memory. Oxford: Oxford University Press.

Leinwand, T. B. 2016. The Great William: Writers Reading Shakespeare. Chicago: Univesity of Chicago Press.

Marušič, J. 2011. Poets and mimesis in the Republic. - P. Destrée, F.-G. Herrmann, eds., Plato and the Poets. Leiden and Boston: Brill, 217-240.

Meek, R. 2014. Narrating the Visual in Shakespeare. Farnham, Surrey: Ashgate.

Michel, A. 1960. Rhétorique et philosophie chez Cicéron: essai sur les fondements philosophiques de l'art de persuader. Paris: Presses Universitaires.

Miller, G. D. 2011. Mimesis and Reason: Habermas's Political Philosophy. Albany: State University Press of New York.

Montaigne, M. de. 1906 [1588]. Essais de Michel Seignevr de Montaigne Rpt. as Les Essais de Montaigne: reproduuction typographique de l'exemplaire annoté par l'auteur et conservé à la Bibliothèque de Bordeaux avec un avertisssement et une notice par $M$. Ernest Courbet, 4 vols., Paris: Imprimerie Nationale.

Montaigne, M de. 1921. Montaigne's Essays: John Florio's translation. 2 vols. J. I. M. Stewart, ed. London: Nonesuch Press.

Moss, J. 2012. Art and ethical perspective - Notes on the Kalon in Plato's Laws. - A. Denham, ed., Plato on Art and Beauty. Houndsmills: Palgrave, 205-220.

Mualem, S. 2012. Borges and Plato: A Game with Shifting Mirrors. Madrid: Iberoamericana; Frankfurt am Main: Vervuert.

Muir, K. 1977. The Sources of Shakespeare's Plays. London: Methuen.

Naddaff, R. 2002. Exiling the Poets: The production of Censorship in Plato's Republic. Chicago: University of Chicago Press.

Nehamas, A. 1982. Plato on imitation and poetry in Republic 10. - J. M. E. Moravcsik, P. Temko, eds., Plato on Beauty, Wisdom, and the Arts. Totowa, NJ: Rowan \& Littlefield, 47-78.

Notomi, N. 2011. Image-making in Republic X and the Sophist: Plato's criticism of the poet and the sophist. - P. Destrée, F.-G. Herrmann, eds., Plato and the poets. Leiden and Boston: Brill, 299-326.

Nussbaum, M. 1980. Aristophanes and Socrates on learning practical wisdom. - Yale Classical Studies, 26, 433-97.

Pagden, A. 1986 [1982]. The Fall of Natural Man: The American Indian and the Origins of Comparative Ethnography. Rev. ed. Cambridge: Cambridge University Press.

Palumbo, L. 2013. Mimesis in the Sophist. - B. Bossi, T. M. Robinson, eds., Plato's Sophist Revisited. Berlin: De Gruyter, 269-278.

Pappas, N. 2016. Plato's aesthetics. - E. N. Zalta, ed., The Stanford Encyclopedia of Philosophy, Fall 2016 Edition. https://plato.stanford.edu/archives/fall2016/entries/ plato-aesthetics/ (13.11.2017).

Pettersson, B. 2016. How Literary Worlds Are Shaped: A Comparative Poetics of Literary Imagination. Berlin: De Gruyter.

Plato. 1997. Plato: Complete Works. J. Cooper, ed. Indianapolis: Hackett.

Plato. 2000. Republic. B. Jowett, trans. New York: Dover Books. 
HART

Quinn, D. B. 1971. European technology and preconceptions. - W. P. Cumming, R. A. Skelton, D. B. Quinn, eds., The Discovery of North America. London: Paul Elek, 13-18.

Quint, D. 1995. A Reconsideration of Montaigne's Des cannibals. - K. O. Kupperman, ed., America in European Consciousness, 1493-1750. Chapel Hill: University of North Carolina Press, 166-191.

Ritscher, L. A. 2009. The Semiotics of Rape in Renaissance English Literature. New York: Peter Lang.

Said, E. 1978. Orientalism. New York: Pantheon.

Saint-Lu, A. 1982. Las Casas, Las Casas indigeniste: études sur la vie et l'oeuvre du défenseur des Indiens. Paris: Éditions L'Harmattan.

Sanchez, M. E. 2013. Erotic Subjects: The Sexuality of Politics in Early Modern Literature. Oxford: Oxford University Press.

Shakespeare, W. 1997. The Riverside Shakespeare. Second Edition. G. B. Evans, J. J. M. Tobin, eds. Boston: Houghton Mifflin.

Singpurwalla, R. 2011. Soul division and mimesis in Republic X. - P. Destrée, F.-G. Herrmann, eds., Plato and the Poets. Leiden and Boston: Brill, 283-298.

Starks-Estes, L. S. 2014. Violence, Trauma, and Virtus in Shakespeare's Roman Poems and Plays: Transforming Ovid. New York: Palgrave Macmillan.

Woodruff, P. 2015. Mimesis. - P. Destrée, P. Murray, eds., A Companion to Ancient Aesthetics. Malden, MA: Wiley Blackwell, 329-340.

Worth, I. 1988. Practicing Translation in Renaissance France: The Example of Étienne Dolet. Oxford: Clarendon Press.

Zakai, A. 2017. Erich Auerbach and the Crisis of German Philology: The Humanist Tradition in Peril. Switzerland: Springer Verlag. 